\title{
PENGARUH E-SPT PAJAK PENGHASILAN DAN PEMAHAMAN PAJAK TERHADAP KEPATUHAN WAJIB PAJAK
}

http://jurnal.usbypkp.ac.id/index.php/sikap

\author{
Sabil \\ Akademi Manajemen Keuangan BSI Jakarta \\ sabil.sbl@bsi.ac.id \\ Dwiyatmoko Pujiwidodo \\ Akademi Manajemen Keuangan BSI Jakarta \\ dwiyatmoko.dpw@bsi.ac.id \\ Amin Setio Lestiningsih \\ Akademi Manajemen Keuangan BSI Jakarta \\ amin.asl@bsi.ac.id
}

\begin{abstract}
Improving the quality of tax service to the taxpayer the Directorate General of Taxes apply electronic system (e-SPT) in tax reporting. The purpose of this study is to determine the effect of the application of e-SPT Personal PPH and the understanding of taxation on taxpayer compliance. This research uses survey method and multiple regression analysis. Data collection is done by using questionnaires distributed to individual taxpayers. Based on the results of research can be concluded that the implementation of e-SPT Personal PPH and understanding taxation significantly influence 55.3\% of taxpayer compliance and $44.7 \%$ influenced by other factors.
\end{abstract}

Keywords: e-SPT Personal Income Tax, Tax Understanding, Taxpayer Compliance

\begin{abstract}
Abstrak
Peningkatan kualitas pelayanan pajak terhadap wajib pajak maka DirektoratJenderal Pajak menerapkan sistem elektronik (e-SPT) dalam pelaporan pajak. Tujuan dari penelitian ini adalah untuk mengetahui pengaruh dari penerapan e-SPT PPH orang pribadi dan pemahaman perpajakan terhadap kepatuhan wajib pajak. Penelitian ini menggunakan metode survey dan analisis regresi berganda. Pengumpulan data dilakukan dengan menggunakan kuesioner yang disebarkan kepada wajib pajak orang pribadi. Berdasarkan hasil penelitian dapat disimpulkan bahwa penerapan e-SPT PPH Orang Pribadi dan pemahaman perpajakan berpengaruh secara signifikan sebesar 55,3\% terhadap kepatuhan wajib pajak dan 44,7\% dipengaruhi oleh faktor-faktor lain.
\end{abstract}

Kata kunci: e-SPT PPh Orang Pribadi, Pemahaman Perpajakan, Kepatuhan Wajib Pajak 


\section{PENDAHULUAN}

Pajak merupakan salah satu sumber pembiayaan pembangunan nasional dalam rangka peningkatan kesejahteraan masyarakat dan kontribusi penerimaan pajak terhadap penerimaan negara diharapkan semakin meningkat dari tahun ke tahun. Realisasi penerimaan pajak tahun 2017mencapai Rp. 1.339,8triliun atau sebesar 91\% dari APBN-P 2017. Dari total penerimaan pajak tersebut, Pajak Penghasilan (PPh) memberikan kontribusi yang paling besar yaitu sebesar Rp. 1.147,59 triliun. Mengingat begitu besarnya kontribusi pajak dalam pembangunan, maka penting adanya kesadaran dan peran masyarakat untuk membayar pajak. Pemerintah berharap dengan meningkatnya kesadaran atau pemahaman masyarakat tentang pentingnya pajak dapat meningkatkan kepatuhan wajib pajak dalam melaksanakan kewajiban perpajakannya.

Pelaporan Pajak Penghasilan oleh wajib pajak dilakukan dengan menyampaikan Surat Pemberitahuan (SPT). Surat Pemberitahuan (SPT) ini diharapkan dapat menjadi sarana bagi wajib pajak untuk melaporkan dan mempertanggungjawabkan perhitungan jumlah pajak yang sebenarnya terutang. Dalam sistem administrasi perpajakan modern, pemerintah menyediakan aplikasi yang dapat digunakan oleh wajib pajak untuk melakukan pengisian dan pelaporan SPT secara tepat, cepat, dan akurat, yang meliputi e-registration, e-filling, e-SPT. Pemerintah berharap dengan adanya e-SPT dapat memberi kemudahan bagi wajib pajak untuk melaporkan kewajiban perpajakannya dan pada akhirnya dapat kepatuhan dari wajib pajak .

Hasil Penelitian menyimpulkan bahwa penerapan e-SPT berpengaruh secara signifikan terhadap kepatuhan Wajib Pajak. Kepatuhan Wajib Pajak dipengaruhi oleh penerapan e-SPT sebesar 33,7\%, sisanya 66,3\% dipengaruhi oleh faktor-faktor lain yang tidak diamati dalam penelitian ini (Lingga, Pengaruh Penerapan e-SPT Terhadap Kepatuhan Pajak: Studi Empiris Terhadap Pengusaha Kena Pajak di Wilayah KPP Pratama “X” Jawa Barat I, 2013).

Hasil penelitian memberikan kesimpulan bahwa modernisasi sistem administrasi perpajakan tidak berpengaruh signifikan terhadap varibel dependen yaitu kepatuhan wajib pajak orang pribadi dan untuk wajib pajak badan, ditemukan variabel independen yaitu modernisasi sistem administrasi perpajakan berpengaruh positif dan signifikan terhadap varibel dependen yaitu kepatuhan wajib pajak badan dan dapat diterima atau benar. Hipotesis juga membuktikan bahwa variabel independen yaitu modernisasi sistem administrasi perpajakan berpengaruh positif dan signifikan terhadap varibel dependen yaitu kepatuhan wajib pajak orang pribadi dan dapat diterima atau benar (Sarunan, Pengaruh Modernisasi Sistem Administrasif Perpajakan Terhadap Kepatuhan Wajib Pajak Orang Pribadi dan Wajib Pajak Badan Pada Kantor Pelayanan Pajak Pratama Manado, 2015).

Hasil Penelitian menyimpulkan bahwa Reformasi administrasi perpajakan melalui payment online system berpengaruh terhadap Kepatuhan wajib pajak PPh badan. Artinya reformasi administrasi perpajakan melalui payment online system baik jika kepatuhan wajib 
pajak PPh badan baik (Madayanto, Karamoy, \& Runtu, Analisis Pengaruh Reformasi Administrasi Perpajakan Melalui Payment Online System Terhadap Kepatuhan Wajib Pajak Badan di KPP Pratama Manado, 2015). Hasil Penelitian memberikan kesimpulan bahwa pemahaman wajib pajak secara parsial berpengaruh positif dan signifikan terhadap kepatuhan wajib pajak serta kemanfaatan NPWP, kulitas pelayanan dan sanksi perpajakan secara parsial tidak berpengaruh signifikan terhadap kepatuhan wajib pajak (Masruroh \& Zulaikha, Pengaruh Kemanfaatan NPWP, Pemahaman Wajib Pajak, Kualitas Pelayanan, Sanksi Perpajakan Terhadap Kepatuhan Wajib Pajak (Studi Empiris pada WP OP di Kabupaten Tegal), 2013)

\section{TELAAH LITERATUR DAN PENGEMBANGAN HIPOTESIS}

\section{Pajak}

\section{Pengertian Pajak}

Tax is compulsory contribution from the person, to the government to depray the expenses incurred in the common interest of all, without refence to special benefit conferred (Waluyo, 2011). Dari definisi di atas terlihat adanya kontribusi seseorang yang ditujukan kepada negara tanpa adanya manfaat yang ditujukan secara khusus pada seseorang.

\section{Pengertian Elektronik Surat Pemberitahuan (e-SPT)}

Dalam mewujudkan sistem administrasi perpajakan modern, pemerintah menyediakan aplikasi yang dapat digunakan oleh Wajib Pajak untuk melakukan pengisian dan pelaporan SPT secara tepat, cepat, dan akurat.

1. e-SPT adalah penyampaian SPT dalam bentuk digital ke KPP secara elektronik atau dengan menggunakan media komputer, sedangakan pengertian e-SPT menurut Direktorat Jenderal pajak adalah Surat Pemberitahuan beserta lampiran-lampirannya dalam bentuk digital dan dilaporkan secara elektronik atau dengan menggunakan media komputer yang digunakan untuk membantu wajib pajak dalm melaporkan perhitungan dan pembayaran pajak yang terutang dengan ketentuan peraturan perundang-undangan yang berlaku (Pandiangan, Modernisasi dan Reformasi Pelayanan Perpajakan, 2008)

2. Menurut KEP-88/PJ/2004 Jo KEP-05/PJ/2005, Surat Pemberitahuan adalah Surat pemberitahuan Masa atau Surat Pemberitahuan Tahunan yang berbentuk formulir dalam media computer (e-SPT)

3. Pengertian e-SPT adalah sebagai berikut :

e-SPT adalah penyampaian SPT dalam bentuk digital ke KPP secara elektronik atau dengan menggunakan media computer. Yang dapat diaplikasikan adalah laporan :

a. SPT Masa PPh (e-SPT PPh) 
b. SPT Tahunan PPh (e-SPT PPh)

c. SPT Masa PPN (e-SPT PPN) (Rahayu, Perpajakan Indonesia, 2010)

4. Pengertian e-SPT sebagai berikut :

e-SPT adalah penyampaian SPT dalam bentuk digital ke KPP secara elektronik atau dengan menggunakan computer (Pandiangan, Reformasi Perpajakan, 2007)

Berdasarkan definisi, maka dapat dikatakan pengertian e-SPT merupakan salah satu digitalisasi Surat Pemberitahuan yang bertujuan untuk memudahkan Wajib Pajak dalam membuat dan menyampaikan Surat Pemberitahuan ke Kantor Pelayanan Pajak.

Aplikasi e-SPT merupakan aplikasi yang diberikan secara Cuma-Cuma oleh Direktorat Jenderal Pajak. Dengan menggunakan e-SPT, wajib pajak dapat merekam, memelihara dan men-generate data digital SPT serta mencetak SPT beserta lampirannya.

\section{Kerangka Konseptual}

Penelitian ini menggunakan kerangka konseptual sebagai berikut:

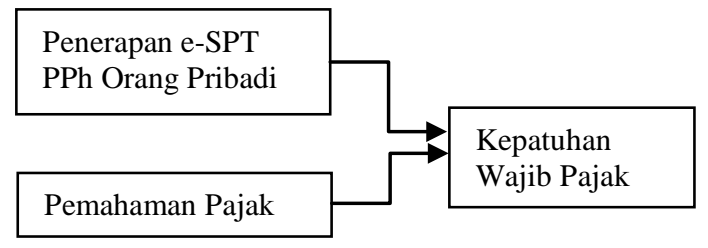

\section{METODE PENELITIAN}

Metode penelitian berupa metode verifikatif digunakan untuk menguji kebenaran teori dan hipotesis yang telah dikemukakan para ahli mengenai keterkaitan antara penerapan e-SPT, pengetahuan perpajakan, dan kepatuhan wajib pajak karyawan. Penelitian ini digunakan untuk menguji pengaruh variabel penerapan e-SPT PPh (X1) dan pemahaman perpajakan (X2) terhadap kepatuhan Wajib Pajak karyawan (Y) yang diteliti apakah diterima atau ditolak. X1 dan X2 merupakan variabel indenpenden sedangkan Y merupakan variabel dependen.

Pengukuran variabel indenpenden dan dependen dilakukan dengan menyebar kuisioner kepada Wajib Pajak.

Jenis data yang digunakan dalam penelitian ini adalah data primer berupa kuesioner dan data sekunder berupa literatur dalam bentuk buku serta jurnal. Teknik pengumpulan data berupa metode survey dengan menyebarkan kuesioner. Teknik analisis data yang digunakan berupa Uji Validitas dan Reliabilitas, uji normalitas, uji heteroskedastistas, uji multikolineritas, uji autokorelasi, analisis regresi berganda, uji korelasi dan uji hipotesis.

Hipotesa yang akan diuji dalam penelitian ini sebagai berikut: 1) $\mathrm{H}_{\mathrm{o}}$ : Tidak ada pengaruh penerapan e-SPT PPh orang pribadi dan pemahaman pajak terhadap 
kepatuhan wajib pajak, 2) $\mathrm{H}_{\mathrm{a}}$ : Ada pengaruh penerapan e-SPT PPh orang pribadi dan pemahaman pajak terhadap kepatuhan wajib pajak.

\section{HASIL DAN PEMBAHASAN}

\section{Analisis Deskriptif Variabel Penerapan E-SPT PPh}

Jumlah item pertanyaan 10 untuk variabel penerapan E-SPT (X1), data hasil penelitian dihimpun dalam tabulasi jawaban responden mengenai penerapan E-SPT PPh data tersebut diolah dan di sajikan dalam persentase, yang dihitung menggunakan bantuan SPSS untuk mencari frekuensi antar item pertanyaan dan persentase.

Berdasarkan hasil penilaian responden item-item pertanyaan dari variabel penerapan E-

SPT

$\mathrm{PPh}$, sebagai

berikut

Tabel 2

\section{Persepsi Responden Terhadap Penerapan E-SPT PPH}

\begin{tabular}{|c|c|c|c|c|c|c|c|c|}
\hline \multirow{2}{*}{$\begin{array}{c}\text { Butir } \\
\text { pertanyaan }\end{array}$} & \multicolumn{5}{|c|}{ Distribusi jawaban Responden } & \multirow{2}{*}{$\begin{array}{c}\text { Skor } \\
\text { Aktual }\end{array}$} & \multirow{2}{*}{ Skor Ideal } & \multirow{2}{*}{$\begin{array}{l}\text { \% Skor } \\
\text { Aktual }\end{array}$} \\
\hline & SS & $\mathbf{S}$ & $\mathbf{R}$ & TS & STS & & & \\
\hline Item 1 & 2 & 21 & 2 & 4 & 1 & 109 & 150 & $73 \%$ \\
\hline Item 2 & 0 & 22 & 4 & 4 & 0 & 108 & 150 & $72 \%$ \\
\hline Item 3 & 3 & 18 & 9 & 0 & 0 & 114 & 150 & $76 \%$ \\
\hline Item 4 & 1 & 15 & 10 & 4 & 0 & 103 & 150 & $69 \%$ \\
\hline Item 5 & 1 & 21 & 5 & 3 & 0 & 110 & 150 & $73 \%$ \\
\hline Item 6 & 1 & 21 & 6 & 2 & 0 & 111 & 150 & $74 \%$ \\
\hline Item 7 & 2 & 21 & 4 & 3 & 0 & 112 & 150 & $75 \%$ \\
\hline Item 8 & 1 & 25 & 4 & 0 & 0 & 117 & 150 & $78 \%$ \\
\hline Item 9 & 2 & 11 & 12 & 3 & 2 & 98 & 150 & $65 \%$ \\
\hline Item 10 & 2 & 10 & 16 & 0 & 2 & 100 & 150 & $67 \%$ \\
\hline jumlah & 15 & 185 & 72 & 23 & 5 & 300 & 585 & 985 \\
\hline$\%$ & $5 \%$ & $62 \%$ & $24 \%$ & $8 \%$ & $1,6 \%$ & & & \\
\hline
\end{tabular}

Sumber : Data diolah (2017)

Berdasarkan tabel diatas, dapat dilihat bahwa tanggapan responden mengenai penerapan E-SPT PPh menunjukan bahwa 5\% responden menjawab sangat setuju, 62\% menjawab setuju, 24\% responden menjawab Ragu, 8\% responden menjawab tidak setuju, 1,6\% responden menjawab sangat tidak setuju. Berdasarkan hasil perhitungan diatas dapat disimpulkan \% responden berpendapat Setuju dalam penerapan E-SPT PPh, karena menurut responden yang menyatakan Setuju dengan penerapan E-SPT PPh ini sangat memudahkan dalam penyampaian Surat Pemberitahuan (SPT) Pajak Penghasilan mereka. Namun sebagian responden masih terdapat yang belum memahami atau megetahui penerapan E-SPT dan masih melakukan penyampaian dengan secara manual dengan datang ke Kantor Pelayanan Pajak. Dan masih ada 
perlu peningkatan dalam penerapan E-SPT terutama pada responden yang masih berpendapat tidak setuju yaitu dalam hal sosialisasi terhadap responden perlu untuk ditingkatkan yang menjadi kurangnya pemahaman terhadap manfaat dan tujuan penerapan E-SPT oleh wajib pajak, serta belum termotivasinya wajib pajak untuk memanfaatkan fasilitas E-SPT ( elektronikSurat Pemberitahuan).

\section{Analisis Deskriptif Variabel Pemahaman Perpajakan}

Jumlah item pertanyaan 10 untuk variabel pemahaman perpajakan (X2), namun karena setiap item pertanyaan dilakukan uji validitas maka hanya 7 item pertanyaan yang dapat dikatakan valid, kerana keterbatasan waktu maka ini data hasil penelitian dihimpun dalam tabulasi jawaban responden mengenai pemahaman perpajakan data tersebut diolah dan di sajikan dalam persentase, yang dihitung menggunakan bantuan SPSS untuk mencari frekuensi antar item pertanyaan dan persentase.

Berdasarkan hasil penilaian responden item-item pertanyaan dari variabel penerapan ESPT PPh, sebagai berikut:

Tabel 3

\section{Persepsi Responden Terhadap Pemahaman Perpajakan}

\begin{tabular}{|c|c|c|c|c|c|c|c|c|}
\hline \multirow{2}{*}{$\begin{array}{c}\text { Butir } \\
\text { pertanyaan }\end{array}$} & \multicolumn{5}{|c|}{ Distribusi jawaban Responden } & \multirow{2}{*}{$\begin{array}{c}\text { Skor } \\
\text { Aktual }\end{array}$} & \multirow{2}{*}{$\begin{array}{l}\text { Skor } \\
\text { Ideal }\end{array}$} & \multirow{2}{*}{$\begin{array}{l}\text { \% Skor } \\
\text { Aktual }\end{array}$} \\
\hline & SS & $\mathbf{S}$ & $\mathbf{R}$ & TS & STS & & & \\
\hline Item 11 & 7 & 15 & 7 & 1 & 0 & 118 & 150 & $79 \%$ \\
\hline Item 12 & 6 & 21 & 3 & 0 & 0 & 123 & 150 & $82 \%$ \\
\hline Item 13 & 2 & 21 & 5 & 2 & 0 & 113 & 150 & $75 \%$ \\
\hline Item 14 & 2 & 22 & 6 & 0 & 0 & 116 & 150 & $77 \%$ \\
\hline Item 15 & 2 & 20 & 4 & 4 & 0 & 110 & 150 & $73 \%$ \\
\hline Item 17 & 8 & 20 & 2 & 0 & 0 & 126 & 150 & $84 \%$ \\
\hline Item 19 & 3 & 20 & 3 & 4 & 0 & 112 & 150 & $75 \%$ \\
\hline jumlah & 30 & 139 & 30 & 11 & 0 & 210 & 1050 & $545 \%$ \\
\hline$\%$ & $1,0 \%$ & $4,6 \%$ & $1,0 \%$ & $0,36 \%$ & $0,0 \%$ & & & \\
\hline
\end{tabular}

Sumber : Data diolah (2017)

Berdasarkan tabel diatas, dapat dilihat bahwa tanggapan responden mengenai pemahaman perpajakan (X2) menunjukan bahwa 1\% responden menjawab sangat setuju, 4,6\% menjawab setuju, $1 \%$ responden menjawab Ragu-Ragu, 0,36\% responden menjawab tidak setuju, $0 \%$ responden menjawab sangat tidak setuju. Berdasarkan hasil perhitungan di atas dapat disimpulkan 5,6\% responden berpendapat bahwa Setuju dan responden memahami system pajak di Indonesia dan paham akan fungsi perpajakan. Namun untuk 0,36\% yang menyatakan tidak setuju akan pemahaman perpajakan ini membuktikan masih ada wajib pajak yang tidak paham akan perpajakan, masalah ini timbul karena masih kurangnya sosialisasi untuk perpajakan. 


\section{Analisis Deskriptif Variabel Kepatuhan wajib pajak karyawan}

Jumlah item pertanyaan 10 untuk variabel kepatuhan wajib pajak (Y), namun karena setiap item pertanyaan dilakukan uji validitas maka hanya 8 item pertanyaan yang dapat dikatakan valid, karena keterbatasan waktu maka ini data hasil penelitian dihimpun dalam tabulasi jawaban responden mengenai kepatuhan wajib pajak data tersebut diolah dan di sajikan dalam persentase, yang dihitung menggunakan bantuan SPSS untuk mencari frekuensi antar item pertanyaan dan persentase.

Berdasarkan hasil penilaian responden item-item pertanyaan dari variabel penerapan ESPT PPh, sebagai berikut:

\section{Tabel 4}

\section{Persepsi Responden Terhadap Kepatuhan Wajib Pajak}

\begin{tabular}{|c|c|c|c|c|c|c|c|c|}
\hline \multirow{2}{*}{$\begin{array}{c}\text { Butir } \\
\text { pertanyaan }\end{array}$} & \multicolumn{5}{|c|}{ Distribusi jawaban Responden } & \multirow{2}{*}{$\begin{array}{c}\text { Skor } \\
\text { Aktual }\end{array}$} & \multirow{2}{*}{$\begin{array}{l}\text { Skor } \\
\text { Ideal }\end{array}$} & \multirow{2}{*}{$\begin{array}{l}\text { \% Skor } \\
\text { Aktual }\end{array}$} \\
\hline & SS & $\mathbf{S}$ & $\mathbf{R}$ & TS & STS & & & \\
\hline Item 11 & 0 & 30 & 0 & 0 & 0 & 120 & 150 & $80 \%$ \\
\hline Item 12 & 0 & 25 & 1 & 3 & 1 & 110 & 150 & $73 \%$ \\
\hline Item 13 & 1 & 22 & 5 & 2 & 0 & 112 & 150 & $75 \%$ \\
\hline Item 14 & 2 & 25 & 3 & 0 & 0 & 119 & 150 & $79 \%$ \\
\hline Item 15 & 2 & 25 & 1 & 2 & 0 & 117 & 150 & $78 \%$ \\
\hline Item 17 & 0 & 28 & 2 & 0 & 0 & 118 & 150 & $79 \%$ \\
\hline Item 19 & 4 & 23 & 2 & 1 & 0 & 120 & 150 & $80 \%$ \\
\hline Item 20 & 1 & 24 & 4 & 1 & 0 & 115 & 150 & $77 \%$ \\
\hline jumlah & 10 & 202 & 18 & 9 & 1 & 931 & 1200 & $621 \%$ \\
\hline$\%$ & $3,3 \%$ & $67 \%$ & $6 \%$ & $3 \%$ & $0,3 \%$ & & & \\
\hline
\end{tabular}

Sumber : Data diolah (2017)

Berdasarkan tabel diatas, dapat dilihat bahwa tanggapan responden mengenai kepatuhan wajib pajak (Y) menunjukan bahwa 3,3\% responden menjawab sangat setuju, 67\% menjawab setuju, 6\% responden menjawab Ragu-Ragu, 3\% responden menjawab tidak setuju, 0,3\% responden menjawab sangat tidak setuju. Berdasarkan hasil perhitungan di atas dapat disimpulkan 70,3\% responden berpendapat bahwa Setuju. Maka disimpulkan responden yang menyatakan setuju meraka sudah patuh akan penyampaian, pembayaran, dan perhitungan terhadap pajak.

\section{A. Uji Validitas dan Reliabilitas}

Data yang akan diberikan kepada sampel terlebih dahulu di analisis uji validitas dan reliability dengan menggunakan statistik perangkat lunak Statistik Produck and Service Solution (SPSS) for windows versi 20.0. pengujian Validitas dan Realibilitas dengan hasil sebagai berikut 
Tabel 5

\section{Hasil Pengujian Validitas Variabel X1}

\begin{tabular}{cccc}
\hline NO & r Hitung & r Kritis & keputusan \\
X1.1 & 0,428 & 0,30 & valid \\
X1.2 & 0,573 & 0,30 & valid \\
\hline X1.3 & 0,379 & 0,30 & valid \\
\hline X1.4 & 0,815 & 0,30 & valid \\
\hline X1.5 & 0,607 & 0,30 & valid \\
\hline X1.6 & 0,504 & 0,30 & valid \\
\hline
\end{tabular}

\begin{tabular}{llll} 
X1.7 & 0,65 & 0,30 & valid \\
\hline $\mathrm{X} 1.8$ & 0,361 & 0,30 & valid \\
\hline $\mathrm{X} 1.9$ & 0,537 & 0,30 & valid \\
\hline $\mathrm{X} 1.10$ & 0,728 & 0,30 & valid
\end{tabular}

Sumber : Data yang diolah (2017)

Berdasarkan tabel 5, terlihat bahwa 10 item untuk variabel X1 menghasilkan keputusan valid sehingga untuk pengujian validitas dan realibitas variabel X1 bisa dipakai untuk penelitian ini.

Tabel 6

\begin{tabular}{cccc}
\multicolumn{4}{c}{ Hasil Pengujian Validitas Variabel X2 } \\
No & r Hitung & r Kritis & keputusan \\
\hline X2.1 & 0,699 & 0,30 & valid \\
\hline X2.2 & 0,732 & 0,30 & valid \\
\hline X2.3 & 0,752 & 0,30 & valid \\
\hline X2.4 & 0,527 & 0,30 & valid \\
\hline X2.5 & 0,497 & 0,30 & valid \\
\hline X2.6 & 0,235 & 0,30 & tidak valid \\
\hline X2.7 & 0,521 & 0,30 & valid \\
\hline X2.8 & 0,177 & 0,30 & tidak valid \\
\hline X2.9 & 0,723 & 0,30 & valid \\
\hline X2.10 & 0,322 & 0,30 & tidak valid \\
\hline
\end{tabular}

Sumber : Data yang diolah (2017)

Berdasarkan tabel 6, untuk pengujian validitas dan reliabilitas variabel X2 dari 10 item pertanyaan dalam kuesioner ada 3 item yang tidak valid yaitu item pertanyaan no 6, 8 dan 10 sehingga untuk 3 item tersebut tidak bisa dipakai untuk penelitian ini. 
Tabel 7

\begin{tabular}{cccc}
\multicolumn{3}{c}{ Hasil Pengujian Validitas Variabel Y } \\
NO & r Hitung & r Kritis & keputusan \\
\hline Y.1 & 0,708 & 0,30 & valid \\
\hline Y.2 & 0,769 & 0,30 & valid \\
\hline Y.3 & 0,737 & 0,30 & valid \\
\hline Y.4 & 0,582 & 0,30 & valid \\
\hline Y.5 & 0,46 & 0,30 & valid \\
\hline Y.6 & 0,211 & 0,30 & Tidak valid \\
\hline Y.7 & 0,589 & 0,30 & valid \\
\hline Y.8 & 0,102 & 0,30 & Tidak valid \\
\hline Y.9 & 0,72 & 0,30 & valid \\
\hline Y.10 & 0,387 & 0,30 & valid
\end{tabular}

Sumber : Data yang diolah (2017)

Berdasarkan hasil pengujian validitas diperoleh hasil bahwa setiap item pernyataan memiliki nilai koefisien korelasi lebih besar dari titik kritis 0,30 sehingga dapat disimpulkan bahwa semua item pertanyaan valid dan sebagian item pertanyaan tidak valid. Item pertanyaan yang tidak valid tidak dapat untuk diuji.

Setelah itu dinyatakan valid, kuesioner harus diuji reliabilitasnya yang menunjukkan sejauh mana pernyataan dapat dipahami sehingga tidak menyebabkan beda interpretasi dalam pemahaman pertanyaan tersebut. Untuk pengujian reliabilitas digunakan metode Cronbach's Alpha. Suatu variabel dapat dikatakan reliabel jika memberikan nilaikoefisien reliabilitas Cronbach's Alpha >0,6.

Tabel 8

\section{Hasil Pengujian Reliabiliti Variabel X1 Reliability Statistics}

\begin{tabular}{ccc}
$\begin{array}{c}\text { Cronbach's } \\
\text { Alpha }\end{array}$ & $\begin{array}{c}\text { Cronbach's } \\
\text { Alpha Based }\end{array}$ & $\begin{array}{c}\mathrm{N} \text { of } \\
\text { Items }\end{array}$ \\
& on & \\
& Standardized \\
& \\
& Items & \\
\hline 0,795 & 0,793 & 10 \\
\hline
\end{tabular}

Berdasarkan hasil pengujian Reliabiliti untuk Variabel X1 pada tabel 8, diketahui bahwa hasil dari Cronbach's Alpha sebesar 0,795. Skor ini menyatakan lebih besar dari 0,6 maka untuk item pertanyaan Variabel X1 dapat dikatakan reliabel. 
Tabel 9

\section{Hasil Pengujian Reliabiliti Variabel X2}

Reliability Statistics

\begin{tabular}{ccc}
$\begin{array}{c}\text { Cronbach's } \\
\text { Alpha }\end{array}$ & $\begin{array}{c}\text { Cronbach's } \\
\text { Alpha Based }\end{array}$ & Items of \\
& on & \\
& Standardized \\
& \\
& Items & \\
\hline 0,791 & 0,81 & 7
\end{tabular}

Berdasarkan hasil pengujian Reliabiliti untuk Variabel X2 pada tabel 9, diketahui bahwa hasil dari Cronbach’s Alpha sebesar 0,791 Skor ini menyatakan lebih besar dari 0,6 maka untuk item pertanyaan Variabel X2 dapat dikatakan reliabel.

Tabel 10

\section{Hasil Pengujian Reliabiliti Variabel Y}

Reliability Statistics

Cronbach's Cronbach's N of

Alpha Alpha Based Items

on

Standardized

Items

\begin{tabular}{lll}
\hline 0,668 & 0,609 & 8 \\
\hline
\end{tabular}

Berdasarkan hasil pengujian Reliabiliti untuk Variabel Y pada tabel IV.9, diketahui bahwa hasil dari Cronbach’s Alpha sebesar 0,668 Skor ini menyatakan lebih besar dari 0,6 maka untuk item pertanyaan Variabel Y dapat dikatakan reliabel.

\section{Pengujian Asumsi Klasik}

\section{Uji Multikolinieritas}

Berdasarkan hasil pengolahan data di peroleh hasil Output Coefficent, yang menunjukan nilai VIF variabel independen X1 dan X2 sebesar 1,167 jauh dari angka 1, juga angka tolerance masih bawah 1 . Hal ini menunjukan dugaan adanya multikolinieritas, yang dalam penelitian ini adanya hubungan antarvariabel penerapan e-SPT dengan variabel Pemahaman perpajakan. 


\section{Uji Autokorelasi}

Berdasarkan perhitungan Model Summary, nilai Durbin-Watson pada tabel sebesar 1,491. Diperoleh nilai du 1,566. Nilai Durbin-Watson 1,491 lebih kecil dari batas atas (du) yakni 1,566 dan terletak antara (4-du) 4- 1,566 = 2,434, maka dapat disimpulkan tidak terjadi autokorelasi

\section{Uji Korelasi}

Koefisien korelasi digunakan untuk mengukur ada atau tidaknya hubungan linier antara variabel indenpenden (X1), (X2) dan variabel dependen (Y) serta mempunyai tujuan untuk menyakinkan bahwa pada kenyataannya terdapat hubungan antara pengaruh penerapan e-SPT $\mathrm{PPh}$ Orang Pribadi dan Pemahaman perpajakan dengan Kepatuhan Wajib pajak. Berdasarkan hasil perhitungan dengan bantuan SPSS, dapat disimpulkan hasil korelasi untuk variabel penerapan e-spt sebesar 0,666 dan variabel pemahaman perpajakan 0,558 berarti menunjukan tingkat hubungan antara variabel korelasinya kuat karena terdapat pada interval koefisien $>0,5-0,75$.

\section{Besar pengaruh penerapan e-SPT PPh Orang Pribadi dan Pemahaman Perpajakan terhadap Kepatuhan Wajib Pajak.}

Dalam penelitian ini menguji seberapa besar pengaruh penerapan e-SPT PPh Orang Pribadi dan pemahaman perpajakan terhadap Kepatuhan Wajib Pajak menurut persepsi Karyawan pada Kantor Akuntan Publik. Hasil jawaban dan analisis data yang dihitung menggunakan SPSS, untuk mengetahui pengaruhnya dilakukan pengujian dengan menggunakan analisis regresi linier berganda dengan model sebagai berikut:

$$
\mathbf{Y}=\mathbf{a}+\mathbf{b} 1 \mathbf{X} 1+\mathbf{b} 2 \mathbf{X} 2
$$

Keterangan:

$\mathrm{Y}=$ variabel dependen ( Kepatuhan Wajib Pajak )

X1 = variabel independen 1 ( Penerapan E-SPT )

X2 = variabel independen 2 ( Pemahaman Perpajakan )

b1 = koefisien regresi yang menunjukan besarnya perubahan satu unit X1

b2 = koefisien regresi yang menunjukan besarnya perubahan satu unit X2 
Tabel 13

Analisis Regresi Linier berganda

Coefficients $^{\mathrm{a}}$

\begin{tabular}{|c|c|c|c|c|c|c|}
\hline \multirow{2}{*}{\multicolumn{2}{|c|}{ Model }} & \multicolumn{2}{|c|}{$\begin{array}{c}\text { Unstandardized } \\
\text { Coefficients }\end{array}$} & \multirow{2}{*}{$\begin{array}{c}\text { Standardized } \\
\text { Coefficients } \\
\text { Beta }\end{array}$} & \multirow[t]{2}{*}{$\mathrm{t}$} & \multirow[t]{2}{*}{ Sig. } \\
\hline & & $\mathrm{B}$ & $\begin{array}{l}\text { Std. } \\
\text { Error }\end{array}$ & & & \\
\hline & $\begin{array}{l}\text { (Constant) } \\
\text { penerapan }\end{array}$ & 15,311 & 4,029 & & 3,8 & 0,001 \\
\hline & $\begin{array}{l}\text { E-SPT } \\
\text { pemahaman }\end{array}$ & 0,314 & 0,082 & 0,53 & 3,814 & 0,001 \\
\hline & pajak & 0,277 & 0,108 & 0,358 & 2,572 & 0,016 \\
\hline
\end{tabular}

a. Dependent Variable: kepatuhan wajib pajak

Berdasarkan hasil pengujian diperoleh model regresi sebagai berikut :

$$
Y=15,311+0,314 X 1+0,277 X 2
$$

Nilai konstantan a memiliki arti bahwa ketika penerapan e-SPT bernilai nol atau kepatuhan tidak berpengaruh oleh penerapan e-SPT, maka rata-rata kepatuhan wajib pajak bernilai 15,311, sedangkan koefisien regresi b1 memiliki arti bahwa jika variabel penerapan eSPT meningkat sebesar satu satuan, maka kepatuhan wajib pajak akan meningkat sebesar 0,314. Dan koefisien regresi b2 memiliki arti bahwa jika variabel pemahaman perpajakan meningkat sebesar satu satuan, maka kepatuhan wajib pajak akan meningkat sebesar 0,277. Koefisien regresi tersebut bernilai positif yang artinya penerapan e-SPT dan pemahaman perpajakan memberikan pengaruh positif terhadap kepatuhan wajib pajak.

\section{Pengujian Hipotesis}

\section{Uji t Hitung}

Hasil $t$ hitung sebesar 3,814 untuk penerapan e-SPT dan 2,572 untuk pemahaman perpajakan. Dengan kata lain karena nilai. P value $<\alpha=0,05$ maka Ho ditolak dan Ha diterima, artinya penerapan e-SPT PPh Orang Pribadi dan Pemahaman Perpajakan berpengaruh secara signifikan terhadap kepatuhan wajib pajak menurut persepsi wajib pajak.

\section{Uji Determinasi}

Hasil nilai R Square sebesar 0.553 artinya besarnya pengaruh dari penerapan e-SPT PPh Orang Pribadi dan pemahaman perpajakan terhadap kepatuhan wajib pajak adalah sebesar 55,3\%, sisanya $44.7 \%$ dipengaruhi oleh faktor-faktor lain yang tidak diamati dalam penelitian ini. 


\section{Uji Hipotesa}

Di simpulkan 16,682 > 1,45 maka, $\mathrm{f}$ hitung > f tabel maka $\mathrm{H}^{\mathrm{o}}$ diterima. Dan nilai signifikansi sebesar 0,000 maka terdapat pengaruh yang signifikan secara bersama-sama antar variabel penerapan e-SPT dan variabel Pemahaman perpajakan.

\section{SIMPULAN}

1. Penerapan e-SPT PPh Orang Pribadi bahwa 5\% responden menjawab sangat setuju, $62 \%$ menjawab setuju, 24\% responden menjawab Ragu, 8\% responden menjawab tidak setuju, 1,6\% responden menjawab sangat tidak setuju. Berdasarkan hasil perhitungan diatas dapat disimpulkan 67\% responden berpendapat Setuju dalam penerapan E-SPT PPh, karena menurut responden yang menyatakan Setuju dengan penerapan E-SPT PPh ini sangat memudahkan dalam penyampaian SuratPemberitahuan (SPT) Pajak Penghasilan mereka. Namun sebagian responden masih terdapat yang belum memahami atau megetahui penerapan E-SPT dan masih melakukan penyampaian dengan secara manual dengan datang ke Kantor Pelayanan Pajak.

2. Pemahaman Perpajakan karyawan menunjukan bahwa tanggapan responden mengenai pemahaman perpajakan (X2) menunjukan bahwa 1\% responden menjawab sangat setuju, 4,6\% menjawab setuju, 1\% responden menjawab Ragu-Ragu, 0,36\% responden menjawab tidak setuju, 0\% responden menjawab sangat tidak setuju. Berdasarkan hasil perhitungan di atas dapat disimpulkan 5,6\% responden berpendapat bahwa Setuju dan responden memahami system pajak di Indonesia dan paham akan fungsi perpajakan. Namun untuk 0,36\% yang menyatakan tidak setuju akan pemahaman perpajakan ini membuktikan masih ada wajib pajak yang tidak paham akan perpajakan, masalah ini timbul karena masih kurangnya sosialisasi untuk perpajakan.

3. Kepatuhan perpajakan wajib pajak menunjukan bahwa 3,3\% responden menjawab sangat setuju, 67\% menjawab setuju, 6\% responden menjawab Ragu-Ragu, 3\% responden menjawab tidak setuju, 0,3\% responden menjawab sangat tidak setuju. Berdasarkan hasil perhitungan di atas dapat disimpulkan 70,3\% responden berpendapat bahwa Setuju. Maka disimpulkan responden yang menyatakan setuju mereka sudah patuh akan penyampaian, pembayaran, dan perhitungan terhadap pajak.

4. Pengaruh Penerapan e-SPT PPh Orang Pribadi dan Pemahaman Perpajakan terhadap kepatuhan wajib pajak disimpulkan berpengaruh secara signifikan sebesar 52\%, sisanya 48\% dipengaruhi oleh faktor-faktor lain yang tidak diamati dalam penelitian ini. 


\section{DAFTAR PUSTAKA}

Lingga, I. S. (2013). Pengaruh Penerapan e-SPT Terhadap Kepatuhan Pajak: Studi Empiris Terhadap Pengusaha Kena Pajak di Wilayah KPP Pratama "X" Jawa Barat I. Jurnal Akuntansi, Vol. 5 No. 1 Mei , ISSN:2085-8698, 1-9.

Madayanto, E., Karamoy, H., \& Runtu, T. (2015). Analisis Pengaruh Reformasi Administrasi Perpajakan Melalui Payment Online System Terhadap Kepatuhan Wajib Pajak Badan di KPP Pratama Manado. Jurnal Berkala Ilmiah Efisiensi, Volume 15 No. 04 , 221-229.

Masruroh, S., \& Zulaikha. (2013). Pengaruh Kemanfaatan NPWP, Pemahaman Wajib Pajak, Kualitas Pelayanan, Sanksi Perpajakan Terhadap Kepatuhan Wajib Pajak (Studi Empiris pada WP OP di Kabupaten Tegal). DIPONEGORO JOURNAL OF ACCOUNTING, Volume 2, Nomor 4, ISSN (Online): 2337-3806 , 1-15.

Pandiangan, L. (2008). Modernisasi dan Reformasi Pelayanan Perpajakan. Jakarta: PT Elex Media Komputindo.

Pandiangan, L. (2007). Reformasi Perpajakan. Jakarta: PT Salemba Empat.

Rahayu, S. K. (2010). Perpajakan Indonesia. Yogyakarta: Graha Ilmu.

Sarunan, W. K. (2015). Pengaruh Modernisasi Sistem Administrasif Perpajakan Terhadap Kepatuhan Wajib Pajak Orang Pribadi dan Wajib Pajak Badan Pada Kantor Pelayanan Pajak Pratama Manado. Jurnal EMBA, Vol.3 No.4 Desember, ISSN 2303-1174 , 518-526.

Waluyo. (2011). Perpajakan Indonesia. Jakarta: Salemba Empat. 